\title{
Assessment of Seismic Behaviour and Safety of a Masonry Heritage
}

Ahmet Murat Turk ${ }^{*}$

\begin{abstract}
Turkey is a highly seismic country where numerous major earthquakes have devastated or damaged the existing historic structures owing to there is a large number of historical structures, mostly religious ones like mosques, and churches. The minarets are essential parts of mosques and there are many of these historic structures across the country which were built since Seljuq Empire started to rule the Anatolia and followed by Ottomans. As Turkey located in a highly active seismic zone, the possible damage of the minarets, the tallest part of the mosques, should be examined and the safety measures, in terms of seismic retrofit, should be considered. It is engineering communities' responsibility to satisfy the longevity of these existing heritages by the help of science and knowledge.

To realize this objective, a case study is planned which addresses the problem of seismic capacity of a stone masonry minaret as a part of the architectural heritage in Istanbul, and a typical historical mosque is chosen. Mathematical model of the minaret is prepared in order to obtain possible deformation profile, lateral displacements, free vibration modes and most likely failure modes under seismic excitation by using response spectrum analysis.
\end{abstract}

Keywords: Historical, heritage structure, minaret, seismic, masonry, performance

*Ph.D., Associate Professor in Civil Engineering Department in Istanbul Kultur University, Turkey ORCID

E-mail: muratturk52@gmail.com 
Most recent developments in the in-situ testing of structures and computational procedures for structural analysis have made reaching to the important results about the behaviour of the old masonry structures. The numerical results have shown that the greatest damage accumulated near the shoe region and the lower part of the shaft. The evaluation of these results is promising in terms of seismic safety of these heritages with minimized intervention on the structure without compromising the authentic view and function.

\section{INTRODUCTION}

In Turkey, which is very rich in terms of cultural heritage, historical structures show a great variety. Due to the presence of Anatolia on an active earthquake zone, historical structures in the country have been affected by earthquakes several times. Some have been damaged and repaired, and some were completely collapsed. Reducing the damages caused by earthquakes is possible with the help of continuous maintenance and monitoring of the architectural heritages. Long periods of ignorance, ongoing construction activity around these structures weakens historical structures and makes them more vulnerable. Due to the problem of protecting the architectural heritage from earthquakes, many countries give the same priority to the work to be done before, during and after the disaster. Such actions should address the strategic, tactical and operational stages of pre-disaster risk assessment, risk mitigation and preparation, emergency response and disaster recovery stages for the management of the risks that may arise by earthquake hazard in historical buildings. The decisions for the restoration and strengthening of historical buildings are required to be based on a comprehensive analysis of their structural behaviour against earthquakes and to comply with accepted international principles for the protection of historical buildings. Because each historical building has its particular design, construction system, material properties and it offers a condition that should be evaluated by examining the present damages in detail. The earthquake damage to be challenged, ground conditions at the site, the characteristics of the structural system should be investigated, and intervention proposals needs to be developed accordingly. The changes and impacts of the suggestions on the existing historical structures needs to be evaluated in terms of protection principles; alternative solutions should be studied if necessary. The main document of international protection rules for such structures is the "International Charter for the Conservation and Restoration of Monuments and Sites (Venice Charter 1964)" which has been adopted and then recognized as a significant statutory document by ICOMOS in 1965. One of the basic principles of the Venice Statute is the implementation of conservation interventions with 
an approach that takes into account the documentary and aesthetic values of historical buildings. Repair of historical buildings built with traditional materials and techniques is required to be cautious, interventions to be made, plan layout, appearance, material and construction systems are not subjected to change. For that reasons, the assessment and the seismic protection of historical heritage structures has remained one of the challenging subjects for the structural engineering community to study and owe to the vastly complex behaviour of the materials, especially under dynamic loading.

Historical structures like city walls, castles, bazaars, mosques and minarets have experienced diverse levels of damages during past earthquakes of Anatolia. As an old city and the capital of different empires, the historical records have shown the devastation of strong earthquakes occurred near Istanbul and across the lands of Anatolia. In Istanbul, more than 550 strong earthquakes have been recorded since the establishment of the city around $330 \mathrm{AC}$ by the Roman Empire. The latest and strong one, produced by the faults near to Istanbul under the sea of Marmara, in 1894 Earthquake, 69 minarets were recorded as heavily damaged, 30 collapsed, across the Old Peninsula (Batur 1994). Since 1894, the city of Istanbul has not been affected by a strong earthquake produced by the fault system bordering the south coasts of the city.

In the religious structures, the height is an important factor to amplify the impression on the public. Consequently, the tall parts of these structures, minarets of mosques can be assumed as the symbols of Islamic architecture. Minarets are often constructed elegantly, as they are visible within a wide area in their neighborhood, and mostly used to hallmark a spot with an Islamic character. For the Islamic architecture, mosques are made of a combination of main dome and sub-domes and minarets which are carried by arches, walls and piers. At least a minaret is essential for each mosque complex which has a slender cylindrical shape where they can be constructed as separate structure near the main part or attached to the roof of the mosque. The typical height of a minaret is changing typically between $10 \mathrm{~m}$ to $70 \mathrm{~m}$ where the topmost part of the minaret is roofed by a conical cap, which is constructed by using a wooden frame covered with zinc sheets.

In order to understand the dynamic behaviour of historical masonry minarets, the use of on-site testing and computational methods have been utilized extensively with the purpose of advancing the life safety and strengthen the historical structures 
against earthquakes. As an example, in-situ dynamic vibration measurement study was performed on the Bezm-i Alem Valide Sultan Mosque (also known as Dolmabahçe Mosque) minarets, and ambient vibration data were recorded with a detailed report (Oguzmert, 2002). An innovative strengthening method for the minarets was proposed in previous analytical studies by using FRP wrapping (Turk and Cosgun 2012, Turk 2013). The behaviour of masonry minarets subjected to dynamic earthquake loading is analyzed and evaluated [Oliveira et al 2011). In other studies, the dry joint masonry test specimens are tested and the results are presented. Under the in-plane combined compressive and shear loading, the structural behaviour and ultimate strength ability, failure mechanisms are studied [Lourenco 2006, Lourenco et al 2005).

Most of the earlier studies show that the dozens of historical minarets in Istanbul pose a serious collapse risk and threat human life in a strong earthquake. Therefore, structural assessment and modelling of these structures attract more attention from conservation societies, and due to the rigid rules of historic preservation of heritage structures, conservation agencies customarily demand less invasive practices in order to protect the view and unique architectural functions.

Despite the durability of historical masonry minarets has been verified over the several decades, the failures and collapses of similar type minarets have been seen during the earthquakes in Turkey in 1999 and prompted of the severity of losses, destruction and long-term consequences. Lately, Istanbul was hit by an earthquake with a magnitude of $\mathrm{M}_{\mathrm{w}}=5.8$ on Sept 26, 2019 . The aftermath of the tremblor, hood and upper part of an existing minaret collapsed, fell onto the mosque attendants (Figure 1). Minaret was built by using reinforced concrete but the performance of the structure even under a moderate earthquake was poor, and the doubts have arisen on other existing minarets including historical masonry ones. 


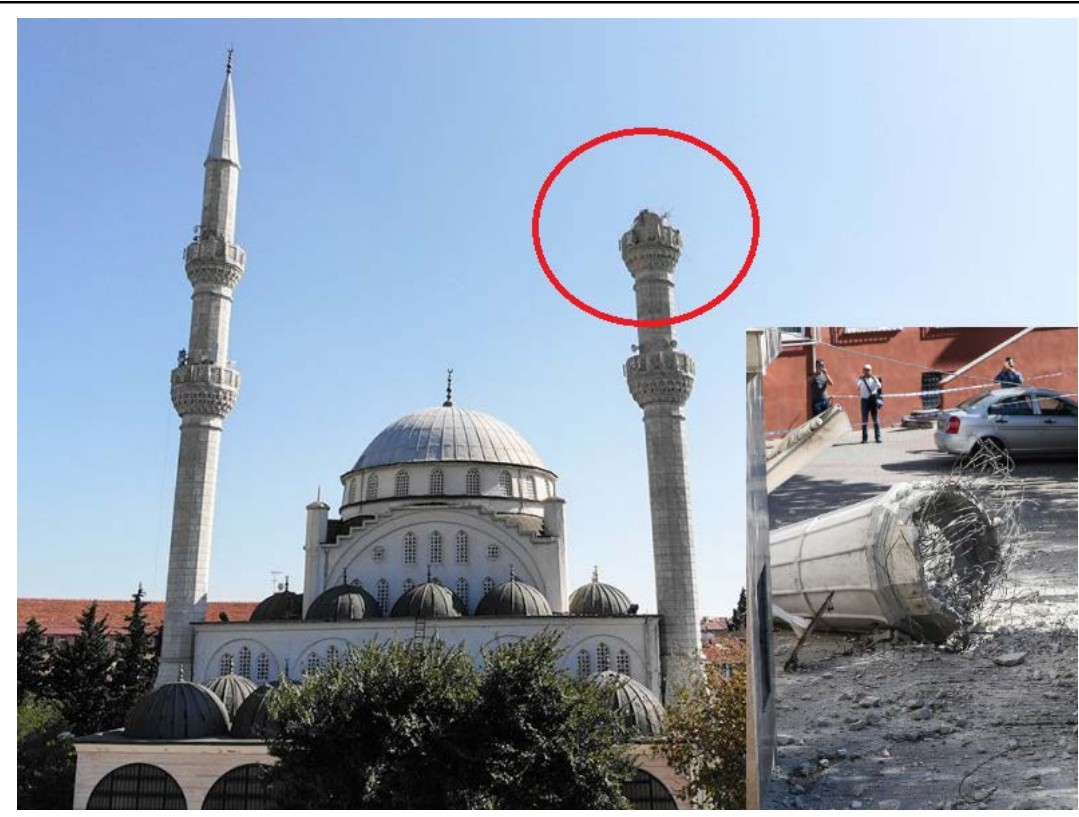

In this study, an existing historical minaret in Istanbul is studied as a case study. By using the on-site-measured structural parameters and the latest version of Turkish Seismic Code (TBDY 2019) which has been in force since January 2019, an analytical study is performed which is different from previous analytical studies (Oğuzmert 2002, Turk and Cosgun 2012, Turk 2013). The minaret structure is studied by using response spectrum analysis following the spectral values defined by the seismic code (TBDY 2019), and the obtained performance levels are discussed according to the "Guidelines for the Management of Earthquake Risks for Historic Structures" published by the General Directorate of Foundations (Tarihi Yapılar İçin Deprem Risklerinin Yönetimi Kılavuzu 2017).

\section{CASE MINARET AND THE PROPERTIES OF THE MATERIALS}

In Figure 2, the general view and physical dimensions are given for the minaret of Bezm-i Alem Valide Sultan Mosque in Istanbul (Turk and Cosgun 2012). The mosque was opened in 1855 on the seafront as a part of the Dolmabahce Palace complex near the European coast of Bosphorus Strait.

The minaret footing is constructed by using very thick polygonal limestone blocks and connected with the main wall of the mosque, consequently fully fixed support assumption is made for the analysis.
Figure 1. Photo of the collapsed minaret in Avcllar, Istanbul (URL 1) 
Figure 2. Photo (taken by author) and the dimensions of the minaret (Turk and Cosgun 2012)
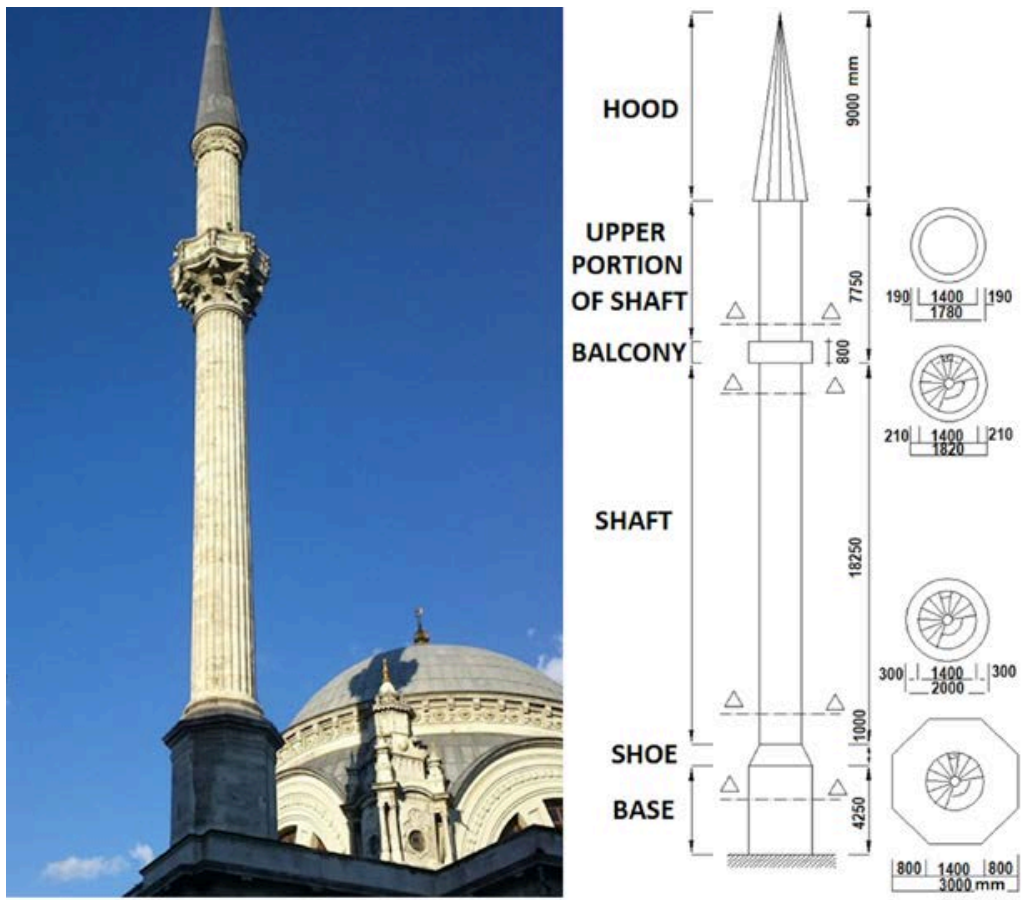

The masonry minaret was constructed by single-leaf, cast-iron clamped limestone blocks (locally it is called as Küfeki stone) similar to all the historical buildings in Istanbul. Küfeki stone has been used for all masonry structures in Istanbul, which was a capital city of the Ottoman Empire. The geological background of the stone belongs to Miocene formation, and it contains $\mathrm{CaCO}_{3}$ (more than $90 \%$ ) and has matrix structure of accumulated and metamorphosed sea shells (Arıoğlu and Arıoğlu 1997, Erguvanlı and Ahunbay 1989, Ahunbay 1988, Arıoglu and Arığlu 1999). In 2000, during the restoration practice of Mosque, material characteristics were determined for the limestone specimens of the minaret as given in Table 1 (Oğuzmert 2002).

Table 1. Mechanical properties of limestone used for the structural analysis

\begin{tabular}{|c|c|c|c|}
\hline Physical Properties of Limestone & Min. & Max. & Average \\
\hline Uniaxial Compressive Strength (MPa) & 12.3 & 19.2 & 16.7 \\
\hline Unit Weight (kN/m $\left.{ }^{3}\right)$ & 22.5 & 24.5 & 23.4 \\
\hline
\end{tabular}

As a result of a previous study on limestones collected from queries near Istanbul, the ratio of elastic modulus, E, on uniaxial compressive strength, $\mathrm{f}_{\mathrm{c}}$, is proposed as 720. (Arıoglu and Arıoglu 1997). For the structural model of the minaret, the modulus of elasticity, E, is assumed as $8856 \mathrm{MPa}$ which is the multiplication of 720 and $\mathrm{f}_{\mathrm{c}}=12.3 \mathrm{MPa}$ (minimum compressive strength of tested 
limestone samples (Table 1). The Poisson ratio and unit weight of the stone are taken as 0.24 and $23.4 \mathrm{kN} / \mathrm{m}^{3}$, respectively in this study.

\section{MODAL AND SPECTRAL ANALYSIS ON THE CASE MINARET STRUCTURAL MODEL}

For the evaluation of the structural performance of the minaret model, a series of modal and spectral analyses are implemented by using the finite element method (FEM). Three-dimensional finite element model is constructed to investigate the dynamic response of the minaret with the ANSYS software. This software has different capabilities like linear, nonlinear, static, dynamic analyses of all types of structures. In this study, linear FEM analyses are performed by employing SOLID 185 elements which use 8 nodes having three degrees of freedom per node and during the analysis 786120 elements and 1239585 nodes are utilized for the minaret model (ANSYS 2018). Masonry is recognized as anisotropic composite material, but through the FEM modelling, a homogeneous isotropic material model approach is chosen by disregarding the mechanical differences between limestone units and mortar joints called as homogenization where the interaction between masonry blocks and mortar is not considered. Simplified linear analysis with the assumption of homogenized material can be utilised as a method for preliminary assessment and evaluation of the need to perform a more compound analysis.

In the model, the bottom of the minaret is assumed as fixed support, soil-structure interaction and base rotation are neglected during the analyses. Linear material behaviour is assumed, and the degradation of the stiffness, material softening and hardening properties are not taken into consideration.

The mosque is located in a highly seismic region with stiff soil layers located near the seashore where soil class is assumed as ZD consistent with seismic code (TBDY 2019) and Type C soil class according to Eurocode 8 and NEHRP (NEHRP 2003). TBDY 2019 describes the limits for ZD soil class with parameters of $15 \leq \mathrm{N} \leq$ 50 and $70 \mathrm{kPa} \leq \mathrm{c}_{\mathrm{u} 30} \leq 250 \mathrm{kPa}$ and $180 \leq \mathrm{V}_{\mathrm{s} 30} \leq 360 \mathrm{~m} / \mathrm{s}$ where $\mathrm{N}$ is SPT blow number, $\mathrm{c}_{\mathrm{u} 30}$ is undrained shear strength, and $\mathrm{V}_{\mathrm{s} 30}$ is defined shear wave velocity for the top $30 \mathrm{~m}$ depth.

In order to simulate a constant damping ratio, $5 \%$ is presumed whereas an earlier study showed that the ambient vibration tests concluded 3-5\% damping those performed on Bosnian historical minarets (URL 2). In a study performed on different minarets near Istanbul, ambient vibration tests showed 0.5-1\% damping for low amplitude motion (Oliveira et al 2011). 
New Turkish Seismic Code imposes a new Earthquake Hazard Map of Turkey containing the geographic location of the structures (URL 3). Mainly, four seismic levels of earthquakes are expected in the safety assessment of the structures: DD-1 (Very rare, with the probability of exceeding over 50 years is $2 \%$ and the return period is 2475 years), DD-2 (Rare, with the probability of exceeding over 50 years is $10 \%$ and the return period is 475 years), DD-3 (Occasional, with the probability of exceeding over 50 years is $50 \%$ and the return period is 72 years) and DD-4 (Frequent, with the probability of exceeding over 50 years is $68 \%$ and the return period is 43 years) (Figure 3 ). The horizontal and vertical elastic spectra of these earthquakes are defined in the code on reference ground conditions for a particular earthquake level. In historical buildings, it is generally sufficient to consider the horizontal earthquake component. However, it may be necessary to consider the vertical earthquake component in large openings or cantilevers.

Figure 3. Peak ground acceleration map for 475 years return period $(10$ $\%$ exceedance in 50 years) (URL 4)

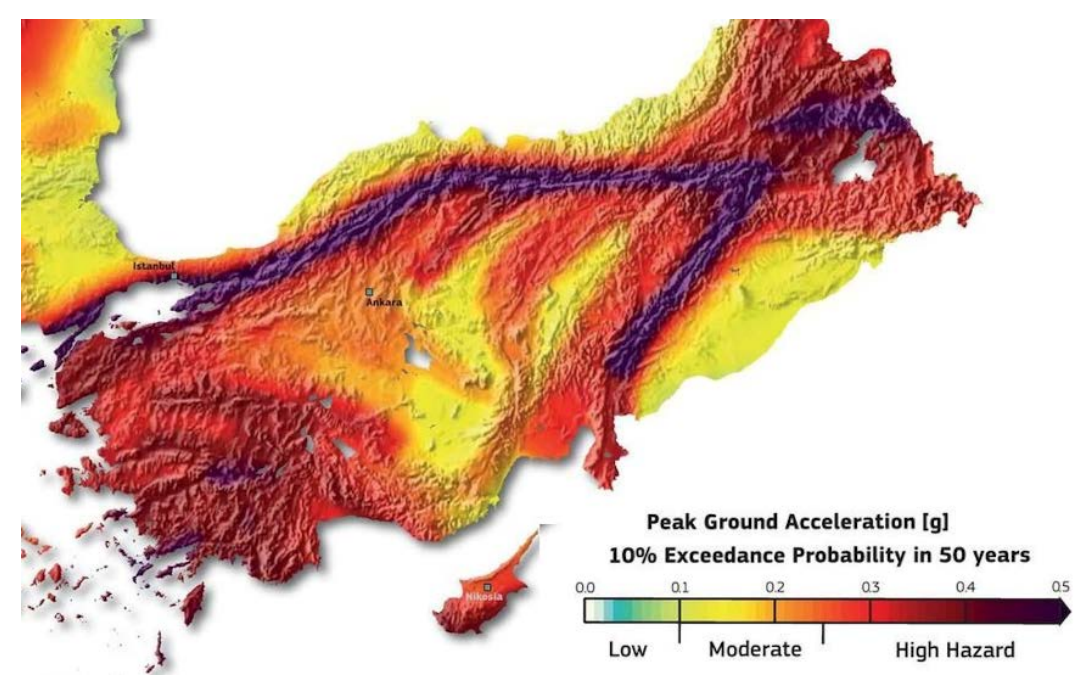

Special earthquake hazard analyses and site-specific earthquake spectra are required to determine the importance of the structure evaluated. DD-1, DD-2, DD-3 and DD-4 level spectral acceleration values are prepared according to the rules of Turkish Seismic Code 2019 by considering local site soil conditions (Figure 4) (TBDY 2019).

Turkish Seismic Code does not contain any specific instructions regarding the seismic assessment of historical masonry structures. Besides, Clause 3.5.1.2 imposes attainment of life safety (LS) performance level for all masonry structures under the impact of DD-2 level earthquake. For the minaret, Turkish Seismic Code 2019 offers to use the seismic load reduction factor $\left(R_{a}\right)$, over strength factor (D) and as and building importance factor I parameters as $\mathrm{R}=2.5, \mathrm{D}=1.5$ and $\mathrm{I}=1.0$, respectively. Seismic 
reduction factor, $R_{a}$, equations are given as below where $T_{B}$ is given as corner period for the horizontal elastic acceleration spectra (TBDY 2019).

$$
\begin{gathered}
R_{a}(T)=\frac{R}{I} \quad \text { if } T>T_{B} \\
R_{a}(T)=D+\left(\frac{R}{I}-D\right) \frac{T}{T_{B}} \text { if } T \leq T_{B}
\end{gathered}
$$

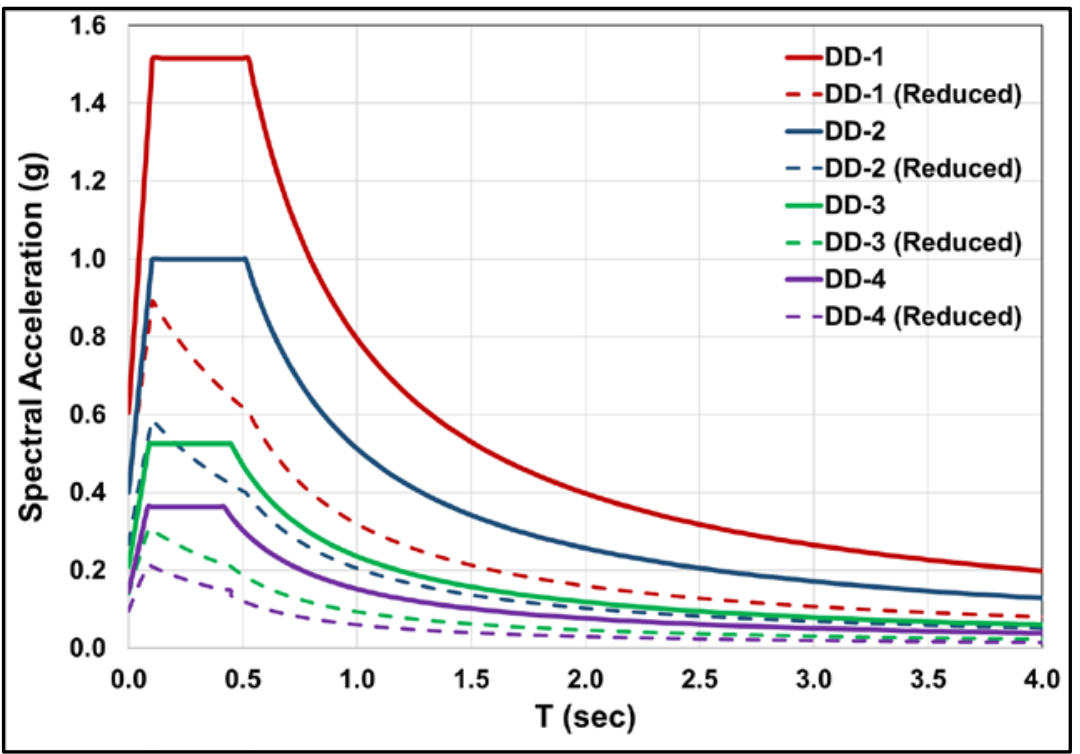

Beside the Seismic Code, the seismic performance of the minaret structure is determined according to the performance limit conditions given in the "Guidelines for the Management of Earthquake Risks for Historic Structures" (Tarihi Yapılar İçin Deprem Risklerinin Yönetimi Kılavuzu 2017). In order to assess the lateral deformation performance, the guidelines adopt the coefficient of $R_{a}$ as unity for elastic FEM analysis (Table 2, Table 3 ). Besides, for the determination of performance in terms of strength, seismic load reduction factor, $\mathrm{R}_{\mathrm{a}}$, shall be considered as $1 \leq \mathrm{Ra} \leq 3$ where it is taken as 2.5 for the structural minaret model.

Turkish Seismic Code imposes "Life Safety" performance level for masonry structures under the impact of DD-2 seismic hazard level. Besides, "Guidelines for the Management of Earthquake Risks for Historic Structures" recommends different performance levels for historical structures according to their importance in the local, national and global scale. In this study, the minaret has been categorized as a nationally important heritage structure. Consequently, the performance states are considered as three different seismic hazard level; DD-1, DD-2 and DD-3 (Figure 5, Table 2 and Table 3).
Figure 4. Acceleration response spectra predicted for the location by Turkish Seismic Code 2019 (TBDY 2019) 
Figure 5. Recommended performance levels for a typical historical masonry structure

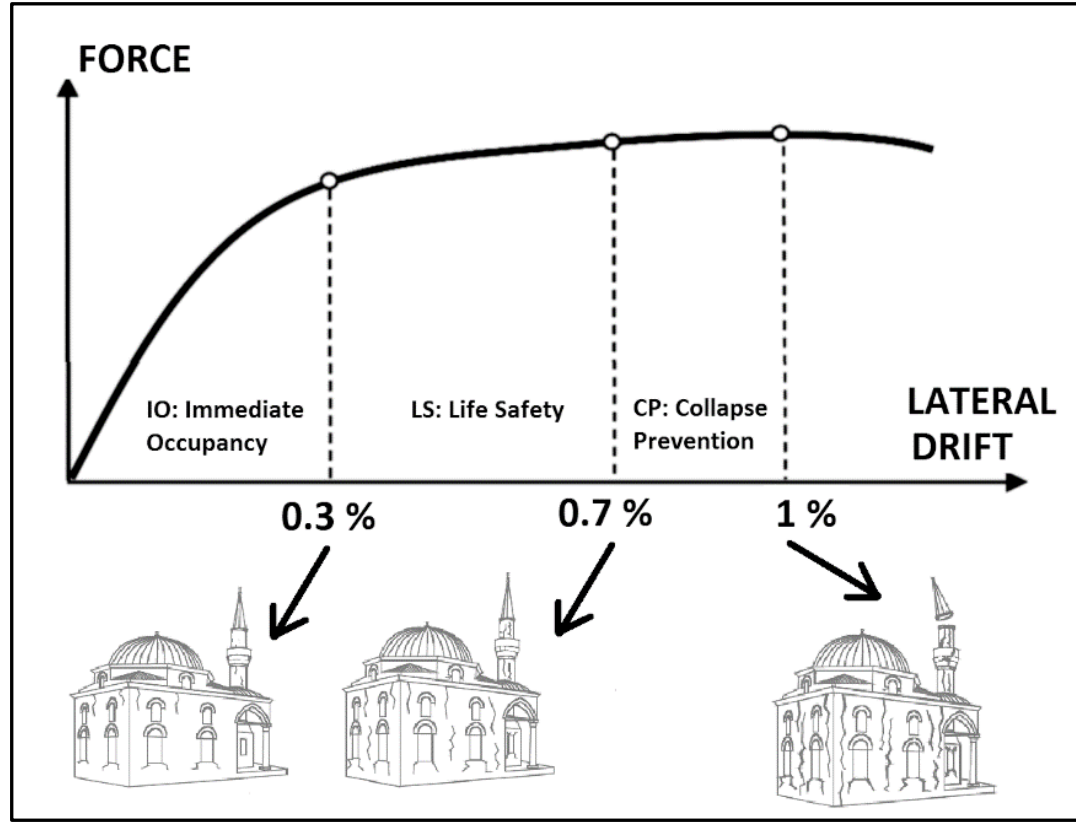

Table 2. Recommended performance levels for historical structures which have nationwide importance under the effect of different seismic hazard levels

\begin{tabular}{|c|c|}
\hline Seismic Hazard Level & Performance State Attained \\
\hline DD-3 & Immediate Occupancy (IO) \\
\hline DD-2 & Life Safety (LS) \\
\hline DD-1 & Collapse Prevention (CP) \\
\hline
\end{tabular}

Table 3. Recommended for the assessment of historical structures for different performance states

\begin{tabular}{|c|c|}
\hline Performance State Attained & \\
\hline Immediate Occupancy (IO) & $\begin{array}{l}\text { Elastic analysis; } \\
\text { a) Material strength is not exceeded } \\
\text { (where } R_{a}=1 \text { ) } \\
\text { b) Maximum lateral drift ratio does not } \\
\text { exceed } 0.3 \% \quad \text { (where } R_{a}=1 \text { ) }\end{array}$ \\
\hline Life Safety (LS) & $\begin{array}{l}\text { Elastic analysis; } \\
\text { a) Material strength is not exceeded } \\
\text { (where } 1 \leq R_{a} \leq 3 \text { ) } \\
\text { b) Maximum lateral drift ratio does not } \\
\text { exceed } 0.7 \% \text { (where } R_{a}=1 \text { ) }\end{array}$ \\
\hline Collapse Prevention (CP) & $\begin{array}{l}\text { Elastic analysis; } \\
\text { a) Material strength can be exceeded by } 50 \\
\% \text { (where } 1 \leq \mathrm{R}_{\mathrm{a}} \leq 3 \text { ) } \\
\text { b) Maximum lateral drift ratio does not } \\
\text { exceed } 1.0 \% \text { (where } \mathrm{R}_{\mathrm{a}}=1 \text { ) } \\
\mathrm{R}_{\mathrm{a}}=\text { Seismic load reduction factor }\end{array}$ \\
\hline
\end{tabular}


In a previously performed in-situ tests on the case minaret, the fundamental period had been measured as $1.136 \mathrm{sec}(0.88 \mathrm{~Hz})$ after a micro tremor study by using ambient vibrations (Oğuzmert 2002). By using the mechanical properties of the limestone given in Table 1 and the macro modelling approach, finite element model of the case minaret is constructed, including inner stairs and hood. The highest six periods of the the minaret model are given in Table 4 where the mode shapes of the structural model are shown in Figure 6. Fundamental period is calculated as 1.119 sec. which is $2 \%$ different than the measured value during ambient vibration tests as $1.136 \mathrm{sec}$.

Table 4. The calculated periods of minaret FEM model

\begin{tabular}{|c|c|c|}
\hline \multirow{2}{*}{} & \multicolumn{2}{|c|}{ Minaret Model } \\
\cline { 2 - 3 } & T (sec) & Direction \\
\hline Mode 1 & 1.119 & Lateral \\
\hline Mode 2 & 1.118 & Lateral \\
\hline Mode 3 & 0.216 & Lateral \\
\hline Mode 4 & 0.216 & Lateral \\
\hline Mode 5 & 0.092 & Lateral \\
\hline Mode 6 & 0.092 & Lateral \\
\hline
\end{tabular}

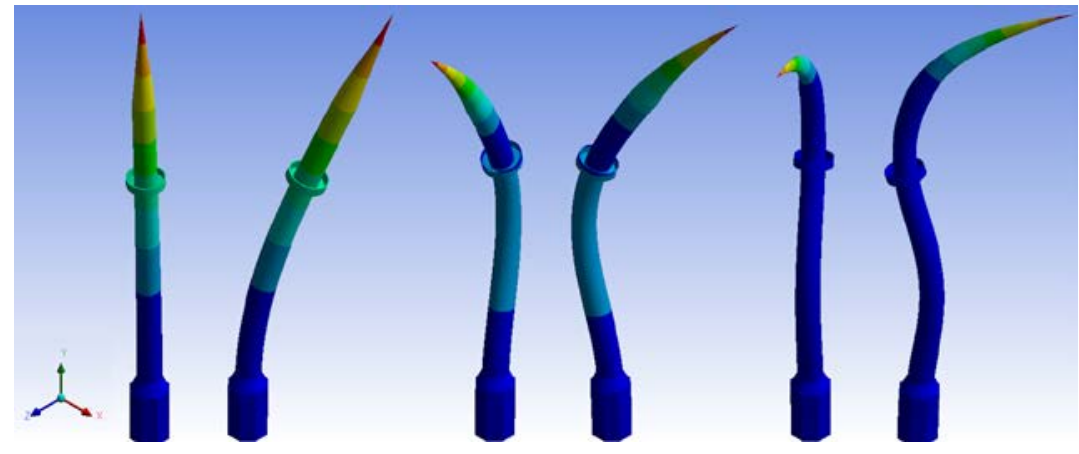

Owing to the similarity of natural periods of the minaret that had been measured on-site and are calculated by dynamic analysis, the mechanical properties employed in the analysis are agreed valid for further analysis, response spectrum analysis, and performance evaluations.

\section{RESULTS OF THE RESPONSE SPECTRUM ANALYSIS}

Minaret model is analyzed under the effect of lateral loading with the help of the response spectrum method. The top of the upper shaft and bottom of the hood therewithal is assumed as the
Figure 6. Mode shapes of the minaret model (Mode 1 to 6 are lined up, left to right) 
reference point for roof displacement calculation. Therefore, the roof height of the minaret model is considered as $31250 \mathrm{~mm}$ ignoring the hood. The obtained deflected shapes of the minaret models under dynamic loading are flexure dominated, and largest lateral displacements occurred at the roof acting as a cantilever structure. Table 5 summarizes the calculated maximum lateral displacements under the effect of DD-1, DD-2, DD-3 and DD-4 level seismic hazard for the case of $R_{a}=1$.

Table 5. Maximum lateral displacements of top of minaret according to response spectrum analyses for different seismic hazard levels

\begin{tabular}{|c|c|c|}
\hline & $\begin{array}{c}\text { Calculated maximum } \\
\text { lateral top } \\
\text { displacement (mm) }\end{array}$ & $\begin{array}{l}\text { Calculated maximum } \\
\text { lateral drift ratio } \\
(\mathrm{mm} / \mathrm{mm})\end{array}$ \\
\hline DD-1 $\left(R_{a}=1\right)$ & 354 & $1.13 \%$ \\
\hline DD-2 $\left(R_{a}=1\right)$ & 228 & $0.72 \%$ \\
\hline DD-3 $\left(R_{a}=1\right)$ & 104 & $0.33 \%$ \\
\hline DD-4 $\left(\mathrm{R}_{\mathrm{a}}=1\right)$ & 67 & $0.21 \%$ \\
\hline
\end{tabular}

The spectral analyses are completed for both elastic and inelastic behaviour assumption where $R_{a}$ is calculated according to code (TBDY 2019). The maximum roof elastic drift ratios of minaret model are calculated as $1.13 \%, 0.72 \%, 0.33 \%$ and $0.21 \%$ for DD1, DD-2, DD-3 and DD-4 seismic hazard levels respectively (Figure 7). According to the limits defined in Table 3, calculated lateral drift ratios appear over the limits.

Figure 7. Top displacements of minaret model in case of DD-1, DD2 , DD-3 and DD-4 seismic hazard levels 
For the minaret model, highest maximum equivalent stress distributions are given in Figure 8. Those are prepared for different seismic hazard levels. The maximum tensile stress on the masonry has been calculated as $8.38 \mathrm{MPa}$ which is greater than the uniaxial tensile strength of masonry, calculated as $2 \mathrm{MPa}$ nearly. Abovementioned possible tensile stress value seems higher than the limiting tensile strength of the material for unreinforced and unconfined cross-sections.

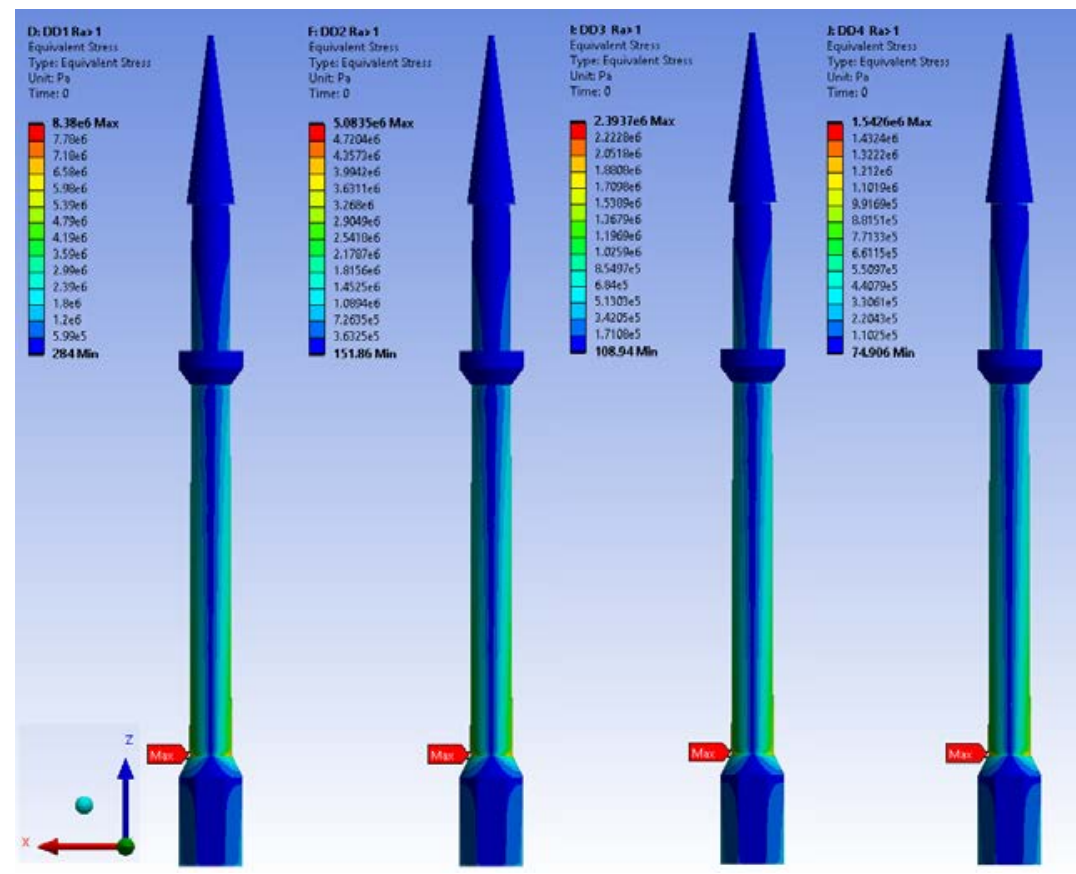

In Figure 8, the maximum tensile stresses obtained for the model subjected to DD-1, DD-2 and DD-3 are bigger than the limited tensile strength of masonry. So, according to the guidelines, stresses exceeded the allowable strengths. In terms of deformation and strength capabilities, the minaret should be concluded as unsafe.

Evaluating the stress distributions on the structure indicates the critical failure zones. Masonry has nonlinear material properties and concluding the results of the linear elastic analysis may cause misjudgment about deformation and strength, especially for collapse prevention performance target. To overcome this problem, a nonlinear analysis should be followed by using nonlinear material properties for masonry material.

As stated by the results of FEM analysis, high tensile stresses arose, especially above the shoe zone (Figure 2) causes the masonry minaret tagged as unsafe against seismic loadings.

Under these conditions, the architectural heritages appear vulnerable in case of rare, occasional and even service
Figure 8. Equivalent elastic stress distribution of model for DD-1, DD2, DD-3 and DD-4 seismic hazard levels $(1 \leq \mathrm{Ra} \leq 2.5)$ 
earthquakes. Due to the complex nature of the problem, the solution is beyond typical engineering practice and demands indepth material information and structural behaviour experience on such type of structures. For the architectural heritage structures, despite it is hard to attain current earthquake demand levels, possible structural interventions should not be bypassed in order to increase the seismic performance without decreasing the architectural value of the structure. After modelling the structural behaviour, the potential weaknesses are discovered and the proper structural intervention method should be selected which has the least impact on the architectural and historical form and texture. Recently, in two different studies, seismic strengthening intervention proposals are given for heritage structures in Italy where the results appears inspiring in terms of safety and conservation of historical structures (Valente and Milani 2019, Micelli and Cascardi 2020).

\section{CONCLUSIONS AND RECOMMENDATIONS}

The main goal of this case study is to increase the understanding of the seismic behaviour of traditional masonry minarets, for providing a basis for future assessment and research. The paper reports the possible failure mode and the seismic safety condition for a typical existing historic minaret structure located in Istanbul owing to the results of FEM analysis. The calculated seismic demand of the minaret, as stated by the current seismic code is compared with the capacity with the aim of defining the most likely mode of failure for the minaret. Lateral deformation and tensile strength capacities are exceeded in case of a strong earthquake $(10 \%$ probability of exceedance in 50 years with 475 years return period) and flexural failure causes collapse.

Analyses show that the most vulnerable part of the minaret is right above the shoe zone, and this matches the real cases seen during the latest earthquakes in Turkey 1999. So as to eliminate possible damage risk for existing minarets, the weakest zones shall be retrofitted by confining or jacketing the masonry with relatively high strength materials.

For further research, proper and feasible retrofit methods should be examined by utilizing the nonlinear material models for dynamic loading, and the in-situ seismic instrumentation shall be installed in order to understand the real behaviour under seismic loading. 


\section{REFERENCES}

Ahunbay, Z. (1988). Mimar Sinan Yapılarında Kullanılan Yapım Teknikleri ve Malzeme. In, Mimarbaşı Kocasinan Yaşadı̆̆ı Çağ ve Eserleri I, (pp. 531-538), Istanbul, Vakıflar Genel Müdürlüğü Yayınları.

ANSYS. (2018). “Academic Research Mechanical”, Release 17.2.0, Pittsburgh, Pennsylvania.

Arıoğlu, N., Arıoğlu, E. (1997). “Mimar Sinan’ın Sectiği Taş: Küfeki ve Clekme Dayanımı", Paper presented at the 14. Türkiye İnşaat Mühendisliği Teknik Kongresi, İzmir. Turkey.

Arıoğlu, E., Arıoğlu, N. (1999). "Mimar Sinan'ın Taşıyıcı Olarak Kullandığı Küfeki Taşının Mühendislik Gizemi", Paper presented at the Mimar Sinan Dönemi Yapı Etkinlikleri Semineri, İstanbul, Turkey.

Batur, A. (1994). 1894 Yazı Pek Heyecanlı Geçmişti, Bir Depremin Yüzyıl Dönümü“. İstanbul Dergisi, 10, 25-32.

Erguvanl, K., Ahunbay, Z. (1989). Mimar Sinan'ın Istanbul'daki Eserlerinde Kullandığı Taşlarin Mühendislik Jeolojisi ve Mimari Ozellikleri. Mühendislik Jeolojisi Bülteni, 11, 109114.

Eurocode 8 (1998). Design of Structures for Earthquake Resistance.

Lourenco, P.B. (2006). Recommendations for Restoration of Ancient Buildings and the Survival of a Masonry Chimney. Construction and Building Materials, 20, 239-251.

Lourenco, P.B., Oliveira, D.V., Roca, P., Orduna, A. (2005). Dry Joint Stone Masonry Walls Subjected to In-Plane Combined Loading. Journal of Structural Engineering, 131(11), 16651673.

Micelli, F., Cascardi, A. (2020) Structural assessment and seismic analysis of a 14th century masonry tower. Engineering Failure Analysis, 107, 104198.

NEHRP (2003). Recommended Provisions for Seismic Regulations for New Buildings and Other Structures, FEMA 4501/2003 Edition.

Oğuzmert, M. (2002). Yığma Minarelerin Dinamik Davranışı, İstanbul Teknik Üniversitesi, Fen Bilimleri Enstitüsü, Yüksek Lisans Tezi, İstanbul.

Oliveira, C.S., Cakti, E., Stengel, D., Branco, M. (2011). Minaret behaviour under earthquake loading: The case of historical Istanbul. Earthquake Engineering and Structural Dynamics, 41(1), 19-39.

Tarihi Yapılar İçin Deprem Risklerinin Yönetimi Kılavuzu (2017). Vakıflar Genel Müdürlügüu, Istanbul.

TBDY 2019 (2109). Türkiye Bina Deprem Yönetmeliği, İçişleri Bakanlığı, Afet ve Acil Durum Yönetimi Başkanlığı, Ankara.

Turk, A.M., Cosgun, C. (2012). Seismic Behaviour and Retrofit of Historic Masonry Minaret, Gradevinar, 64(1), 39-45.

Turk, A.M. (2013). Seismic Response Analysis of Masonry Minaret and Possible Strengthening by Fiber Reinforced Cementitious Matrix (FRCM) Materials. Advances in Materials Science and Engineering, Vol. 2013, Article ID 952497. 
Valente, M., Milani, G. (2019) Advanced Numerical Insights into Failure Analysis and Strengthening of Monumental Masonry Churches Under Seismic Actions. Engineering Failure Analysis, 103, 410-430.

Venice Statue. (1964). International charter for the conservation and restoration of monuments and sites (the Venice Charter 1964).

(URL 1) https://www.diyanethaber.com.tr/diyanet-haber/sondakika-istanbul-da-minare-yikildi--h7533.html

(URL 2) New integrated knowledge based approaches to the protection of cultural heritage from earthquake-induced risk. http://www.niker.eu/.

(URL 3) AFAD, İçişleri Bakanlığı, Afet ve Acil Durum Yönetimi Başkanlığl, https://tdth.afad.gov.tr/TDTH/main.xhtml

(URL 4) SHARE-EU. http://www.share-eu.org, European Seismic Hazard Maps.

\section{Resume}

Ahmet Murat Turk, graduated from Bogazici University, Department of Civil Engineering in 1991. He received M.Sc. degree in 1994 and Ph.D degree in Structural Engineering from Bogazici University. He had worked as Post-Doctoral Research Associate at School of Civil Engineering of Purdue University between 1999 and 2000. Currently, Dr. Turk is holding the position of Associate Professor of Civil Engineering in Istanbul Kultur University. 